\title{
Information Achievements of Prehistory in the Panorama of Archaeological Cultures in the Urals and Western Siberia
}

\author{
O. N. Korochkova
}

For citation: Korochkova O. N. Information Achievements of Prehistory in the Panorama of Archaeological Cultures in the Urals and Western Siberia. Vestnik of Saint Petersburg University. History, 2021, vol.66, issue 2, pp. 549-566. https://doi.org/10.21638/11701/spbu02.2021.214

Our focus is the type of responses the population of the taiga zone of the Urals and Western Siberia gave to cognitive challenges, as well as dynamics and rhythms of information breakthroughs of the Stone-Early Iron Age. The existence of multi-directional migration corridors indicated formation of an extremely diverse anthropological, linguistic and cultural composition of the taiga pioneer population, thus creating natural communication barriers in the context of severe inter-group competition for resources. Against this background, in the Neolithic $\left(7^{\text {th }}-5^{\text {th }}\right.$ millenniums BC), a practice of building fortified settlements, hill-forts, and "sacrificial hills" became widespread - and that was not typical of hunters and fishermen. Erection of those complex and labor-consuming structures required mobilization of a significant number of people, as well as resources and expertise, and contributed to group consolidation in a new territory. It was that type of dramatic disruption that occurred at the turn of the $3^{\text {rd }}$ and $2^{\text {nd }}$ millenniums BC. Considerable changes in the way of life of the taiga population came as a direct result of the "metallurgical revolution". The development of independent metallurgical centers in the Middle Urals traditional ideas about the inability of the population of the appropriating lifestyle to adopt transformative strategies. The northernmost regions became another watershed in the region. The turn of the Eras was marked by development in reindeer herding, which was accompanied by a series of discoveries in the fields of food production, transport development, communications, trade, and symbolic activities. Archaeological data directly indicate the formation of adequate responses and information breakthroughs to the cognitive challenges of the high latitudes of Eurasia, and explain the variety of forms of socio-ideological adaptations and evolutionary alternatives.

Keywords: taiga, Stone Age, Bronze Age, Iron Age, information breakthroughs, cognitive challenges, symbolic activities, fortifications, metallurgical revolution, reindeer herding revolution.

Olga N. Korochkova - Dr. Sci. (History), Professor, Ural Federal University, 19, ul. Mira, Yekaterinburg, 620002, Russian Federation; Olga.Korochkova@urfu.ru

Ольга Николаевна Корочкова - д-р ист. наук, проф., Уральский федеральный университет, Российская Федерация, 6220202, Екатеринбург, ул. Мира, 19; Olga.Korochkova@urfu.ru

The reported study was funded by RFBR according to the research project No. 18-09-40011 "Ural and Western Siberia in the archaeological retrospective: most important discoveries, rhythms, phenomena, and the paradoxes of development" и state assignment FEUZ-2020-0056.

Статья подготовлена при поддержке гранта РФФИ № 18-09-40011 «Урал и Западная Сибирь в археологической ретроспективе: важнейшие открытия, ритмы, феномены и парадоксы развития» и госзадания FEUZ-2020-0056.

(C) St. Petersburg State University, 2021 


\section{Информационные достижения первобытности в панораме археологических культур Урала и Западной Сибири}

\section{О. Н. Корочкова}

Для цитирования: Korochkova O.N. Information Achievements of Prehistory in the Panorama of Archaeological Cultures in the Urals and Western Siberia // Вестник Санкт-Петербургского университета. История. 2021. Т. 66. Вып. 2. С. 549-566.

https://doi.org/10.21638/11701/spbu02.2021.214

В центре внимания автора статьи - реакции населения таежной зоны Урала и Западной Сибири на когнитивные вызовы эпох камня - раннего железа, динамика и ритмы информационных прорывов населения эпох камня - раннего железа. Разнонаправленные миграционные коридоры и растянутый период освоения региона обусловили пестрый антропологический, языковой и культурный состав таежных пионеров, что создавало естественные коммуникационные барьеры в условиях межгрупповой конкуренции за ресурсы. На этом фоне в неолите (7-5-е тыс. до н.э.) получает распространение нетипичная для охотников и рыболовов практика возведения укрепленных поселений и городищ, «жертвенных холмов». Строительство сложных и трудозатратных сооружений требовало организации большого количества людей, привлечения различных ресурсов и знаний, способствуя консолидации группы на новых территориях. К 3-му тыс. до н. э. в регионе складывается культурная общность. Стабильные условия существования, благоприятная климатическая обстановка, оптимальные стратегии охоты, рыболовства и собирательства, сложившаяся система коммуникаций, демографический рост способствовали усложнению информационной среды. Как ответ на подобное усложнение можно рассматривать феномен погребений, многочисленные наскальные изображения (писаницы), святилища на озерах. Резкий слом, связанный с сейминско-турбинским импульсом, происходит на рубеже 3-го и 2-го тыс. до н. э. Существенные перемены в образе жизни и символических практиках таежного населения - прямое следствие «металлургической революции». Сложение самостоятельных металлургических центров (коптяковско-сейминского эпохи бронзы и иткульского эпохи раннего железного века) на Среднем Урале сломало традиционные представления о неспособности населения присваивающего образа жизни к преобразовательным стратегиям. На рубеже эр в самых северных регионах Урала и Западной Сибири произошло становление оленеводства, которое повлекло за собой череду кардинальных перемен в производстве пищи, развитии транспорта, связей, торговли, символической деятельности. Археологические данные прямо свидетельствуют о формировании адекватных ответов и своего рода прорывов на когнитивные вызовы высоких широт Евразии, объясняют многообразие форм социально-мировоззренческих адаптаций и эволюционных альтернатив.

Ключевые слова: тайга, каменный век, бронзовый век, ранний железный век, информационные взрывы, когнитивные вызовы, символическая деятельность, фортификации, «металлургическая революция», «оленеводческая революция».

\section{Introduction}

An exclusive attribute of humans as a biological species is their capacity for transmission, selective assimilation, generation and amplification of extragenetic non-inherited information, which is the essence of the phenomenon of cultural evolution. Modern means of transmission and storage, as well as the quality of information ensure our direction towards a new "digital" reality, which, according to a neurolinguist T. V. Chernigovskaya's metaphoric remark, gave birth to a "new species" Homo Confusus - "human confused" 
or "human bewildered"1. However, this type of confusion is a natural state of a person in a changing environment forced to respond to information challenges by developing new economic, behavioral, social and ideological strategies. A place of prominence in this line of responses belongs to symbolic practices as the indicators of information explosions leading to various dramatic changes in the life of society. For most people the terms "information revolution" and "information explosion" are associated, in the first place, with modernity and major discoveries related to the transfer of information, i.e. writing, printing, telegraph, telephone, and computer. However, applying an information approach to understanding of culture ${ }^{2}$, we should admit, that transformation is driven, in addition to the means of information transfer, also by its volume, quality, and function. During a greater part of the human history, people used preliterate sign systems continuously elaborating them in response to the incessant cognitive challenges. These achievements are most prominently conveyed in the information explosion concept ${ }^{3}$, which adds a historical content to archaeological periodization and supports a process-based approach to the study of the prehistory phenomena. The concept is based on the phenomenon of radical revolutionary change in understanding the surrounding world, which dramatically transformed the life support, the ideological and the social adaptation strategies: the "first cultural revolution", the "Upper Paleolithic revolution", the "Neolithic", the "metallurgical", and the "herding" 7 revolutions. The chronological dynamics, the territorial selectivity, the factors and mechanisms of cultural translation, and the universality of the consequences, allow us to consider the concept of information explosions as one more research tool for understanding and modeling of the preliterate history processes.

This short introduction offers an outline of the main topics proposed for discussion in this article. Our focus is the type of responses of the population of the taiga zone of the Urals and Western Siberia to cognitive challenges, dynamics and rhythms of the information breakthroughs of the Stone - Early Iron Age.

The territorial (Fig. 1) and the chronological choice is based exclusively on the author's academic background and the longstanding history of field research in the area. In addition, similarly to many of my colleagues and fellow researchers, I believe in the region's huge and underestimated research and interpretation potential ${ }^{8}$. A pronounced conservatism of the taiga cultures is fraught with a colossal epistemic potential, which offers a researcher a vivid picture of the numerous watershed moments of prehistory marked by information breakthroughs.

${ }^{1}$ Chernigovskaya T. V. Lecture "The Human Confused - Homo Confusus and the new digital reality". URL: https://www.youtube.com/watch?v=3V0J_rSA4Zk (accessed: 20.03.2020).

${ }^{2}$ Lotman Yu.M. Kul'tura i informatsiia // Semiosfera. St. Petersburg, 2004. P. 393-395.

3 Sher Ia.A., Vishniatskii L.B., Blednova N.S. Proiskhozhdenie znakovogo povedeniia. Moscow, 2004. P.93-97; Vishnyatsky L. B. Information explosion and image-making // Archaeology, Ethnology and Anthropology of Eurasia. 2005. No. 1. P.51-54.

4 Vishniatskii L. B. Istoriia odnoi sluchainosti. Friazino, 2005. P. 135-144.

5 Vishniatskii L. B. Verkhnepaleoliticheskaia revoliutsiia': geografiia, khronologiia, prichiny // Stratum plius. 2000. No.1. P.245-271.

${ }^{6}$ Chernykh E. N. Kul'tury nomadov v megastrukture Evraziiskogo mira: v 2 t. T.1. Moscow, 2013. P. 98-109.

7 Fedorova N. V., Gusev An. V. Tri revoliutsii Ust'-Poluia // Kunstkamera. 2019. No. 3 (3). P. 196-206.

8 Golovnev A. V. Antropologiya dvizheniya. Ekaterinburg, 2009. P.29-34; Fedorova N. V. Sever Zapadnoj Sibiri v zheleznom veke: tradicii i mobil'nost'. Salexard, 2010. P. 7-9; Fedorova N. V., Gusev An. V. Tri revoliutsii Ust'-Poluia. P. 196-206. 


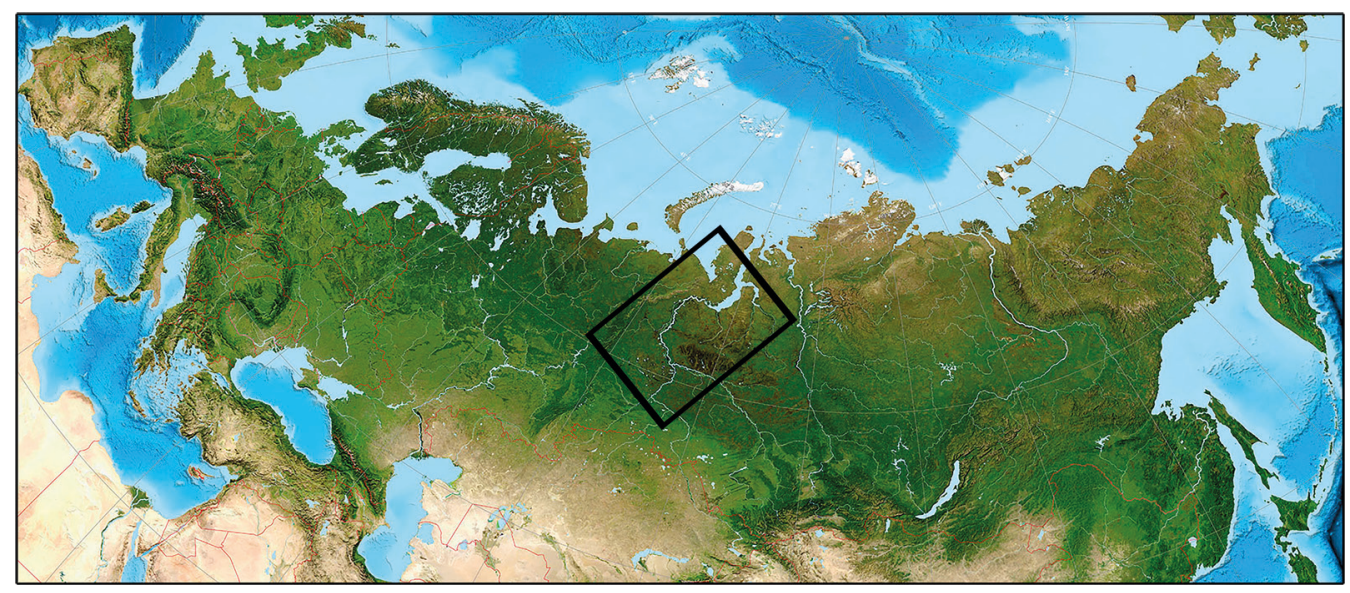

Fig. 1. Ural and Western Siberia on the map of Eurasia (by O. Korochkova)

\section{Stone Age}

The problems of the initial colonization of the Urals and Western Siberia fall into one of the least studied categories. The scarcity of the Paleolithic-Mesolithic archaeological sites is the objective reflection of the pace, rhythm and main routes of human settlement in the region'. Symbolic practices of that period tell us about the existence of sign systems embodied in the rock art of the Upper-Paleolithic caves aged 14,000-10,000 cal. y. a. ${ }^{10}$, the famous Shigir Idol (9,600-9,000 cal. y. a. $)^{11}$ of the Mesolithic; the artifact complexes of the cave and grotto sanctuaries of the Ural ${ }^{12}$ (Fig. 2).

The main inflow of population occurred in the Neolithic. The taiga zone of Western Siberia was a most actively colonized territory. In terms of the number of the Neolithic sites, that area differed significantly from the Trans-Ural, which could be explained by a combination of various factors. That was the time of a climate optimum (the middle-second half of the Holocene Atlantic climate period) characterized by the expansion of the forest zone with the accompanying northward migration of the taiga theriofauna, and the contraction of tundra territory along the Arctic coast ${ }^{13}$. In addition, it coincided with the meridional (south-north) flow of the main rivers, including the Ob, the Irtysh and the Tobol, which supported coastal type of settlements typical of the humans, as well as with the

9 Serikov Iu.B. Paleolit i mezolit Srednego Zaural'ia. Nizhnii Tagil, 2000. P. 30-100; Mosin V.S., Shirokov V.N. Novye paleoliticheskie nakhodki s Iuzhnogo Urala // Rossiiskaia arkheologiia. 2015. No.1. P. 153-156; Pavlov P. Iu. O pervonachal'nom zaselenii severa Urala // Ural'skii istoricheskii vestnik. Ekaterinburg, 2015. No. 2 (47). P.51-56; Zolnikov I.D., Anoikin A.A., Makarov S. S., Postnov A. V., Rezvyi A.S., Glushkova N. V., Bychkov D. A., Tupakhin D. S., Vybornov A. V. O vozmozhnykh putiakh migratsii cheloveka na territoriiu Nizhnego Priob’ia v kamennom veke // Stratum Plus. 2020. No. 1. P. 118-130.

${ }_{10}$ Shirokov V.N. Peshchernoe paleoliticheskoe iskusstvo Urala i Zapadnoi Evropy // Ural'skii istoricheskii vestnik. 2013. No. 4 (41). P.91.

11 Savchenko S. N., Zhilin M. G., Terberger T., Khoissner K. U. Bol'shoi Shigirskii idol v kontekste rannego mezolita Zaural'ia // Ural'skii istoricheskii vestnik. 2018. No. 1 (58). P. 13-14.

12 Serikov Iu. B. Drevnie sviatilishcha Tagil'skogo kraia. Nizhnii Tagil, 2017.

13 Istoriia Iamala. Ekaterinburg, 2010. P. 35-43; Kosintsev P. A., Bachura O. P. Fauna mlekopitaiushchikh severa Zapadnoi Sibiri v pozdnem pleistotsene i golotsene // I Mezhdunarodnaia konferentsiia "Arkheologiia Arktiki”. Salekhard, 2017. P. 13. 

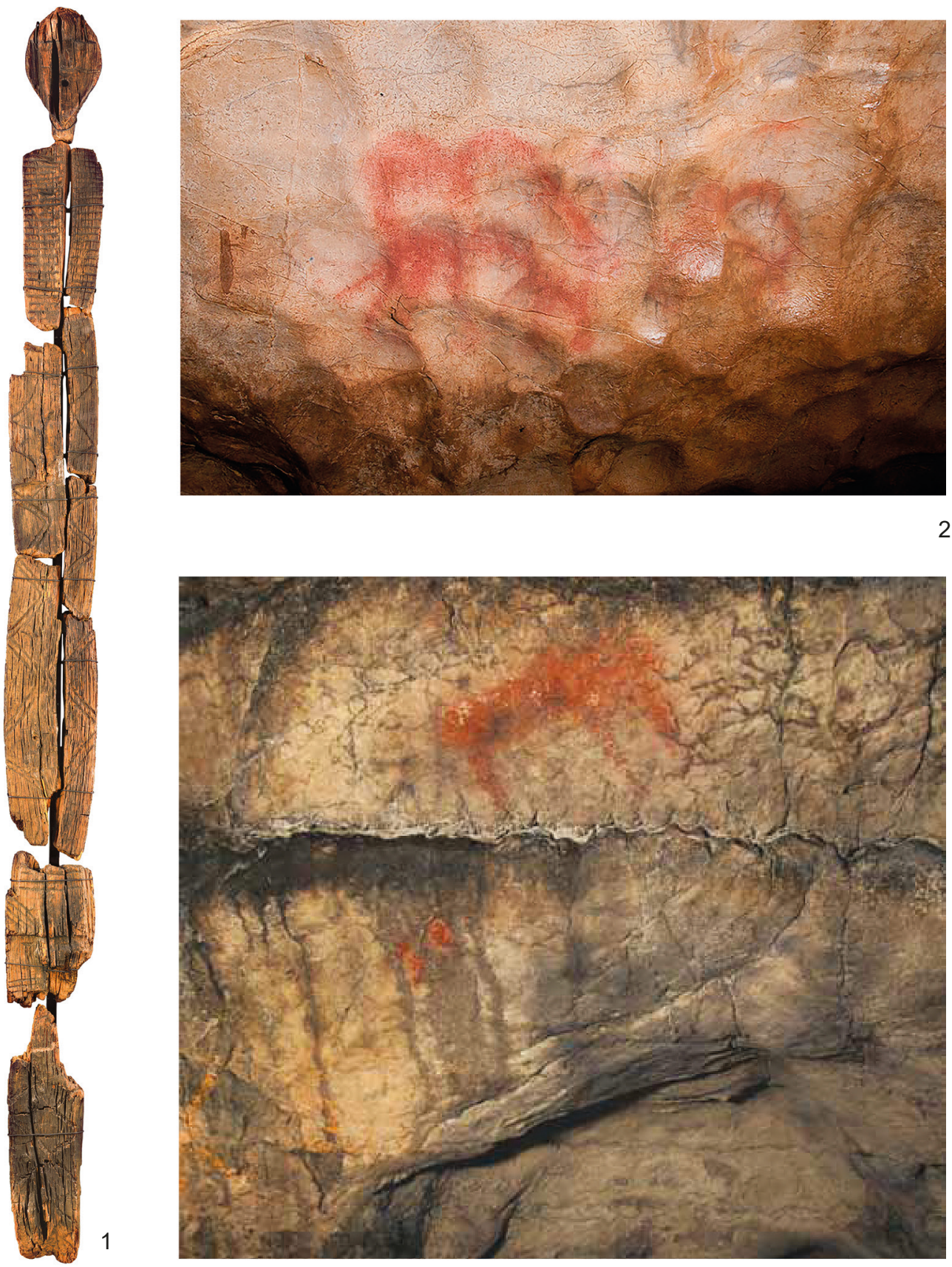

Fig. 2. Artifacts of the Paleolithic-Mesolithic Era: 1 - Great Shigir Idol [Savchenko S. N., Zhilin M. G., Terberger T., Khoissner K. U. Bol'shoi Shigirskii idol v kontekste rannego mezolita Zaural'ia // Ural'skii istoricheskii vestnik, 2018, no. 1]; 2 - Kapova cave [Dubrovsky D. K., Grachev V. Yu. Ural'skie pisanitsy v mirovom naskal'nom iskusstve. Ekaterinburg, 2010]; 3 - Ignatievskaya cave [Shirokov V. N., Petrin V. T. Iskusstvo lednikovogo veka: Ignatievskaia i Serpievskaia 2 peshchery na Iuzhnom Urale. Ekaterinburg, 2013] 
penetrability of the Ural mountains, which, in turn stimulated the latitudinal routes of colonization. The existence of multi-directional migration corridors indicated formation of an extremely diverse anthropological, linguistic and cultural composition of the Siberian pioneer population, thus creating natural communication barriers under the conditions of severe inter-group competition for resources.

The degree of social tensions in the region was reflected in the phenomenon of fortifications unique for the Stone Age in Northern Eurasia (Amnya, Kayukovo 2, Imnjogan $2.1)^{14}$, which combined the state-of-the-art stockade construction techniques and archaic housebuilding practices (Fig. 3: 1a, 2). For instance, in the Amnya hillfort there were 1-2 $\mathrm{m}$ deep pithouses isolated from the outside world by a sophisticated defense system of stockade fences (Fig. 3: 1b, 1c, 1d). The bottom of each pit was covered with ocher. The appearance of fortifications may be interpreted as a response to acute social challenges faced by the new settlers. It is interesting to note the variety of fortification models, which, alongside with the undeniable practical experience of their builders, demonstrated different forms of adjustment of construction skills as well as their adaptation to the environment and a specific situation. These "hillforts" may be viewed as the outpost centers around which all kinds of activities, including religious and mythological, concentrated.

During the same period so-called "sacrificial hills" emerged in the mountain-forest zone of the Trans-Urals and Western Siberia (Koksharov, Ust-Vagil, Makhtyli, Chertova Gora, etc.) They represented complex, 40-50 $\mathrm{m}$ in diameter and 1-5 m high artificial platforms surrounded by moats, on which numerous small (4-25 sq. m) structures were erected (Fig. 3: 3). The unique composition of the finds, the presence of non-residential structures, and the method of the formation of platforms by means of periodical fills prompted researches to interpret the hills as predominantly religious objects ${ }^{15}$.

The erection of these complex and labor-consuming structures (hillforts, "sacrificial hills") required mobilization of a significant number of people, resources and knowledge for their construction, and contributed to group consolidation in a new territory. The emergence of this type of objects in the early Neolithic was indicative of rapid processes of adaptation of the population in the new territories, which necessitated a corresponding mythological and religious support. It was mythology that was at that time a most important tool for the conservation and preservation of the vitally important knowledge and expertise. It was indicative that later this type of fortified and fenced structures disappeared for a long period of time from the practices of the taiga aborigines, which was a reflection of a relatively stable period in the local history in $5^{\text {th }}-3^{\text {rd }}$ millennium BC.

According to the archaeological materials, by the $3^{\text {rd }}$ millennium $\mathrm{BC}$, the Eneolithic cultures the Trans-Ural-North Kazakhstan historic community had evened out ${ }^{16}$. Stable conditions of life, favorable climatic situation, optimal hunting, fishing and gathering strategies, the established communication system, and the demographic growth all together

14 Stefanov V.I., Borzunov V.A. Neoliticheskoe gorodishche Amnia I (po materialam raskopok $1993 \mathrm{i}$ 2000 gg.) // Barsova Gora: Drevnosti taezhnogo Priob'ia. Ekaterinburg; Surgut, 2008. P. 93-11; Borzunov V. A. Neoliticheskie ukreplennye poseleniia Zapadnoi Sibiri i Zaural'ia // Rossiiskaia arkheologiia. 2013. No. 4. P. 20-34; Ivas'ko L. V. Ukreplennoe poselenie kamennogo veka Kaiukovo 2 // Materialy i issledovaniia po istorii Severo-Zapadnoi Sibiri. Ekaterinburg, 2002. P.7-25.

15 Shorin A. F. Koksharovsky Kholm and Chertova Gora, two neolithic sanctuaries in the Urals and in Western Siberia: Similarities and Differences // Archaeology, Ethnology and Anthropology of Eurasia. 2017. Vol. 45 , no. 2. P. $16-25$.

${ }^{16}$ Chairkina N. M. Eneolit Srednego Zaural'ia. Ekaterinburg, 2005. P. 290. 

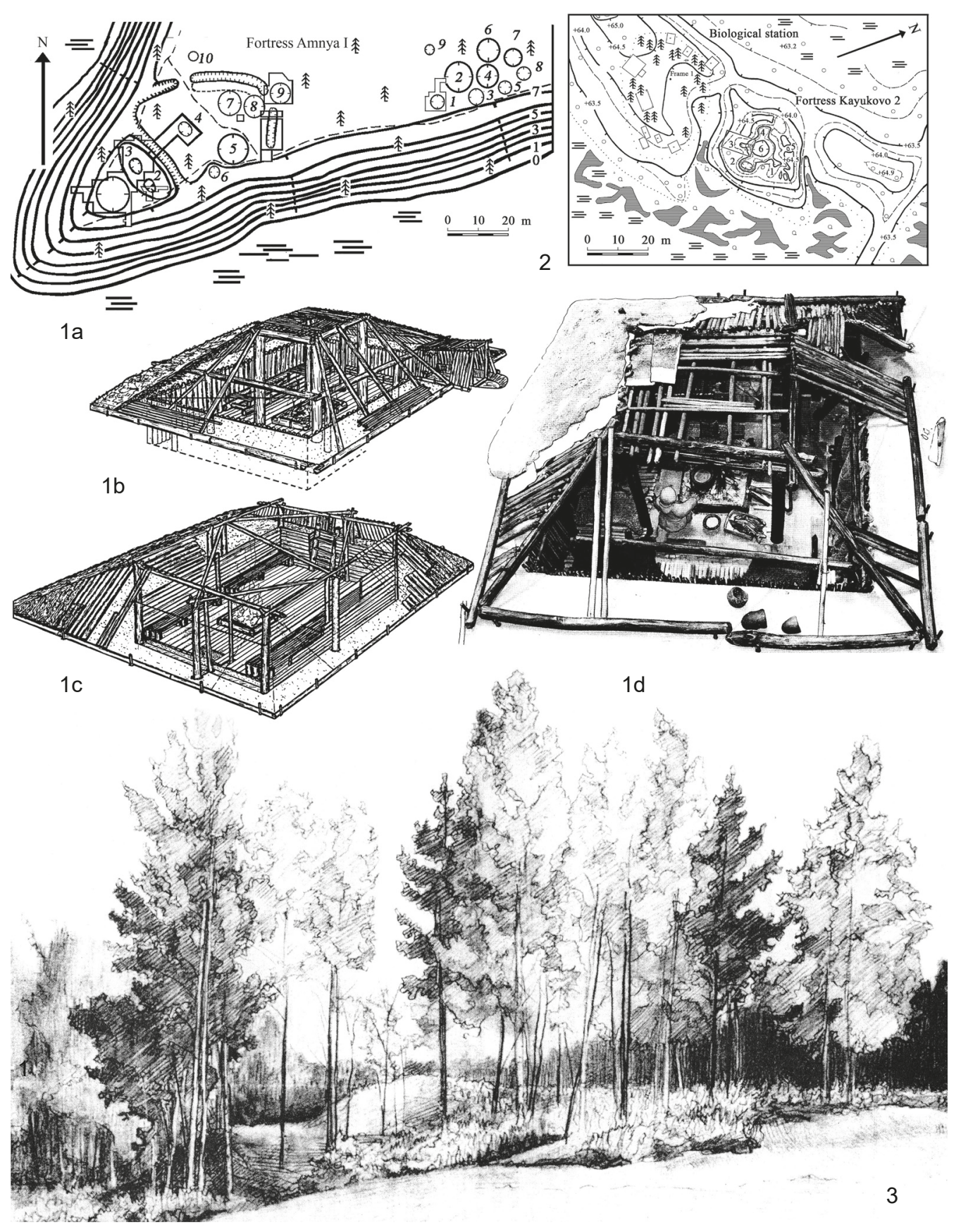

Fig. 3. Neolithic archaeological sites: 1a - hillfort Amnya [Morozov V. M., Stefanov V. I. Amnya I - drevneishee gorodishche Severnoi Evrazii? // Voprosy arkheologii Urala. 1993. Vol. 21. Fig. 1a], 1b, 1c, 1d - reconstruction of dwellings [Borzunov V. A. Varianty rekonstruktsii i tendentsii razvitiia statsionarnykh zhilishch epokh kamnia i bronzy taezhnoi zony Zapadnoi Sibiri // Stratum Plus. 2018. No. 2]; 2 - hillfort Kayukovo [Ivas'ko, 2002]; 3 - "sacrificial hill" Koksharovo [Shorin A. F. Koksharovsky Kholm // Kul’tovye pamiatniki gorno-lesnogo Urala. Ekaterinburg, 2004] 
caused the amplification of the information environment. One of the responses to this amplification was a deliberate burial phenomenon, which formed at the end of the $4^{\text {th }}-3^{\text {rd }}$ millennium $\mathrm{BC}^{17}$. In the mountain-forest zone of the Trans-Urals the symbolic activity of that time was represented by numerous rock art objects: painted panels ${ }^{18}$ (Fig. 4: 2); caves of the sanctuaries (Fig. 4: 3); religious buildings in inaccessible areas of swampy lakes; anthropomorphic (Fig. 4: 1), zoomorphic and ornithomorphic wooden sculptures ${ }^{19}$.

The emergence of the dedicated ritual platforms; rock art panels; burials with the abundance of symbolic signs including the burial ritual itself, the status grave goods, and stone, antler and bone jewelry may be interpreted as a response to a more complex social situation, which required the development of new ideological adaptations to support stability and to ensure maintainenance of the intra-group alliances and the intergroup integration. It is notable that the formation of the burial rituals took place during the "peaceful period" coinciding with the disappearance of the practice of building fortified cape towns, which was replaced with the erection of the individual fortified home-fortresses ${ }^{20}$. The appearance of burials and the individual home-fortresses was an indication of some centrifugal trends, which signalled emerging differentiation of society within the context of settlement in the new, up to then unoccupied territories. During that period people actively settled on the shores of lakes and small rivers. Rich fish resources were, apparently, one of the main stimuli for further colonization of the region.

The resulting life support strategies manifested in the routine culture determined the dynamics and specifics of the historical evolution of the region for several millennia to come. After the early Neolithic, with its abundance of the economic, harvesting, housebuilding and communication experiments, there came a period of supposed stagnation, a general characteristic of a stable period in the history of any culture when it was "changing without change". This is where the specificity of archaeological reflection of the cultural evolution lies. Considerable transformations in the prehistoric life were demonstrated, first of all, in symbolic systems. They were determined by dramatic changes in the lifestyle and related to abrupt information leaps.

\section{Bronze Age}

It was that type of dramatic disruption that occurred at the turn of the $3^{\text {rd }}$ and $2^{\text {nd }}$ millennium BC. Metalworking production and the metal items themselves archaeologically testify changes. The first sporadic metallurgical experiments were stimulated by the information signals coming from the Cis-Ural areas; however, the most vivid episodes were associated with involvement of the taiga regions of Western Siberia and the moun-

17 Korochkova O. N., Mosunova A. V. Eneoliticheskii kompleks poseleniia Duvanskoe XVII // Vestnik arkheologii, antropologii i etnografii. 2018. No.1. P.14-15; Zakh V. A., Zotova S. V., Panfilov A. N. Drevnie mogil'niki na Andreevskom ozere bliz Tiumeni // Drevnie pogrebeniia Ob'-Irtysh'ia. Omsk, 1991. P.1342; Zakh V.A., Skochina S. N., Parkhimovich S. G. Gruntovyi mogil'nik Chepkul' 21 na severe Andreevskoi ozernoi sistemy // Vestnik arkheologii, antropologii i etnografii. 2005. No.6. P.24-42; Matveev A. V., Matveeva N. P., Serikov Iu. B., Skochina S. N. Kul'tovye pamiatniki epokhi eneolita. Tiumen', 2015. P. 60-69.

18 Shirokov V.N., Chairkin S.E. Naskal'nye izobrazheniia Severnogo i Srednego Urala. Ekaterinburg, 2011. P. 130-135.

19 Chairkina N. M. Eneolit Srednego Zaural'ia. P. 238-263.

20 Borzunov V.A. Ukreplennye poseleniia eneolita taezhnogo Priob'ia // Rossiiskaia arkheologiia. 2016. No. 3. P. 34-44. 

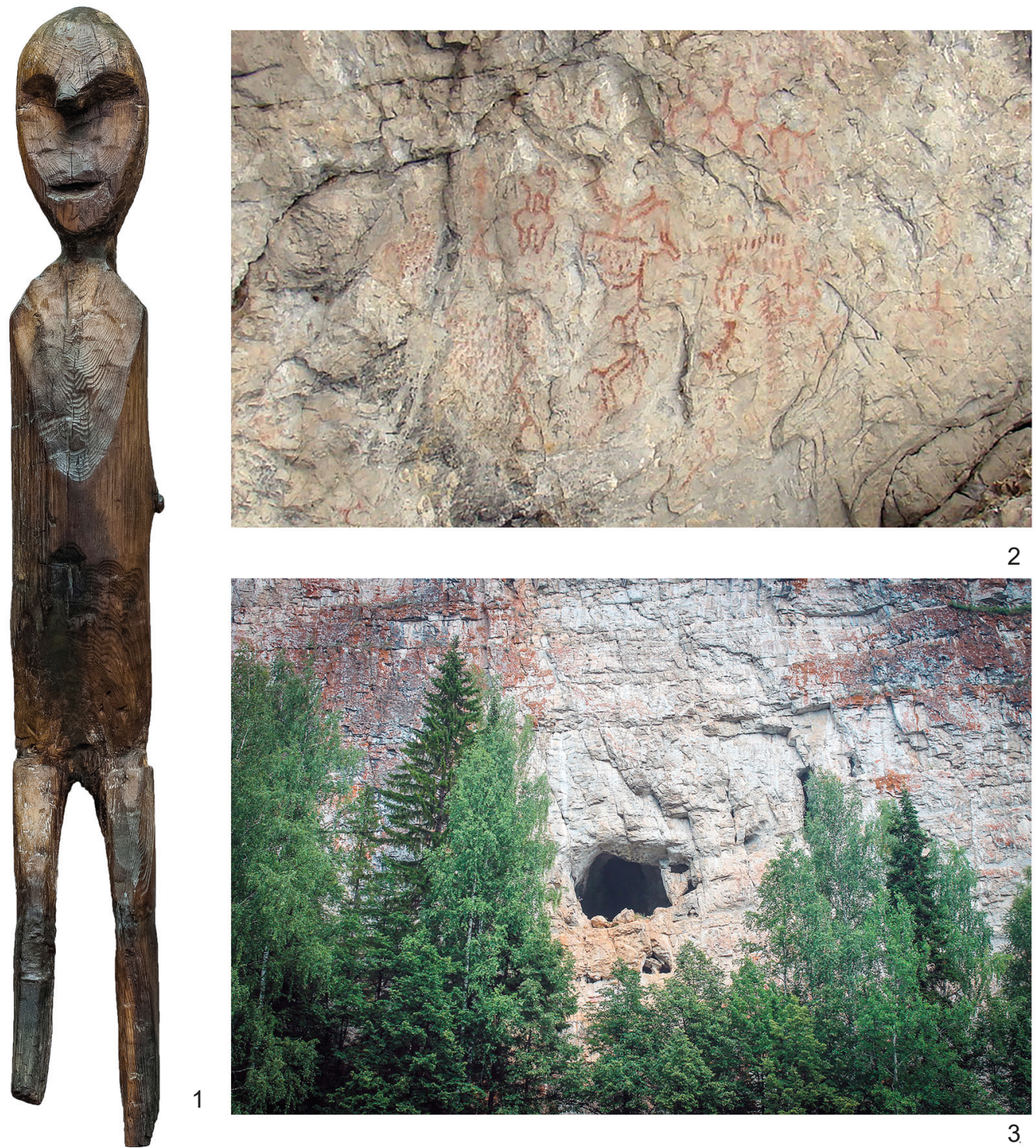

2

1

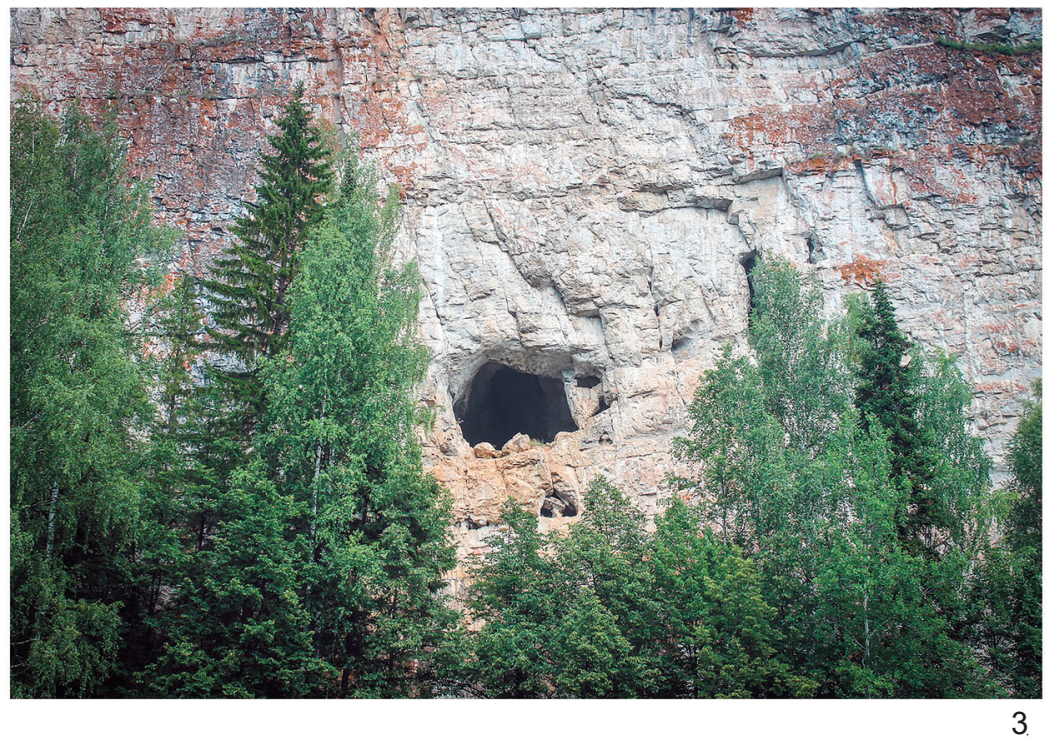

Fig. 4. Cult monuments of the Eneolithic: 1 - Gorbunovo Idol [https://goskatalog.ru/portal/\#/ collections?museumIds=1574\&imageExists=true\&typologyId=6]; 2 - rock art objects "Dvuglazyi Kamen" " [Shirokov V. N., Chairkin S. E., 2011, foto 100]); 3 - Sanctuary Kamen' Dyrovatyi (the Chusovaya river) (foto P. Raspopov)

tain-forest zone of the Trans-Urals into the orbit of the Seima-Turbino migrations. Rapid transformative processes and the change of environment were evident in the appearance of 350-400 sq. m large home-fortresses representing a response to the changed situation, i. e. the emergence of new groups of population armed with bronze weapons and tools ${ }^{21}$.

${ }^{21}$ Korochkova O. N. Srednee Zaural'e i taezhnoe Priob'e v sisteme sviazei Zapadnoaziatskoi metallurgicheskoi provintsii // Vestnik Sankt-Peterburgskogo universiteta. Istoriia. 2019. Vol. 64, no. 2. P.718-739. 
The preferences of the Seima-Turbino migrants for taiga became apparent at a relatively early stage. It is confirmed by the burials Tovkurt-Lor 3 on the Kazym river ${ }^{22}$, Satyga XVI in the Konda lowland ${ }^{23}$, the materials from the settlements of the Kul'egan culture of the late $3^{\text {rd }}$ millennium BC containing several bronze items of the Seima-Turbino type and the attributes of metal casting production ${ }^{24}$. The phenomenon of the Kul'egan culture, localized in the middle $\mathrm{Ob}$ area, deserves closer attention since it may offer some explanation for the early and rapid distribution of "bronze signs" into the heart of the Siberian taiga. This was also stimulated by the $\mathrm{Ob}$ river, the basin of which had become by that time the center of an extensive Krotovo-Elunino cultural domain based on the Seima-Turbino type metallurgy and metal-working. It was that center that gave signals of the new era, new technologies, and new way of life associated with the introduction of metal. However, the traditions of metal production in the taiga of Western Siberia did not take root, and an excessive symbolism of the rare attributes connected with the foundry business prompted a shift of emphasis in interpretation of the first local metal production experiments towards their votive nature ${ }^{25}$. It is noteworthy that the sites of the taiga zone of Western Siberia contained clay nozzles, crucibles, and casting molds, and, by the end of the Bronze Age, also some clay models for spearheads and celts, however the finds of the metal items themselves were quite rare. Another important observation was that the casting molds from the early Bronze Age taiga complexes often had no metal analogues.

A different scenario evolved in the territory of the Middle Trans-Urals with its rich deposits of native copper and oxidized ore outcrops, which met the technological smelting requirements of that time. This fact became a key factor contributing to the development in that area of an independent metallurgical and metalworking Koptyakovo-Seima center ${ }^{26}$. Its unique characteristic was a combination of various technological traditions, i.e. the Seima-Turbino and the steppe "Petrovka-Alakul" tradition. The specific mix of metal and stone tools, and ceramics illustrate the existence of high and varied information potential of the population. The formation of an independent metalworking center in a scarcely populated region lacking any food production potential seems to have been a historical paradox. In fact, the circumstances associated with the existence of that center are far from clear. We still have to rely on the data of the unquestionably unique site the sacred place Shaitanskoe Ozero II (Fig. 5), a small number of the known Koptyakov culture sites and the occasional finds of some metal items ${ }^{27}$. The available dates for the

22 Stefanov V.I. Mogil'nik Tovkurtlor 3: Seiminsko-Turbinskii sled v Nizhnem Priobe // Rossiiskaia arkheologiia. 2006. No. 1. P. 44-58.

${ }^{23}$ Besprozvannyj E.M., Degtyareva A.D., Korochkova O.N., Kuz'minyh S. V., Stefanov V.I., Kosinskaya L. L. Satyga XVI: Seiminsko-turbinskii mogil'nik v taezhnoi zone Zapadnoi Sibiri. Ekaterinburg, 2011. P. 60-86.

${ }^{24}$ Borzunov V.A., Stefanov V.I., Glushkov I. G. Bystry Kulyogan-38 - Bronze Age fortified dwelling in the Surgut Ob area // Archaeology, Ethnology and Anthropology of Eurasia. 2011. Vol. 39, no. 2. P. 55-69.

${ }^{25}$ Korochkova O. N. Srednee Zaural'e... P.727-730.

26 Savinov D. G. O dvukh putiakh rasprostraneniia bronzovykh izdelii seiminskogo tipa na vostok // Arii stepei Evrazii: epokha bronzy i rannego zheleza v stepiakh Evrazii i na sopredel'nykh territoriiakh. Barnaul, 2014. P.91-99.

${ }^{27}$ Korochkova O.N., Stefanov V.I., Spiridonov I.A. Srednee Zaural'e v kontekste Zapadnoaziatskoi Metallurgicheskoi Provintsii: fenomen koptiakovskoi kul'tury // Stratum plus. Arkheologiia i kul'turnaia antropologiia. 2019. No. 2. P. 100-101. 
existence of the sacred site around 1950-1650 BC ${ }^{28}$, spanning quite an extended period of time, apparently also indicate the period of the existence of the production center. The archaeological finds suggested that the sphere of its influence covered mostly the population of the taiga and the forest-steppe Tobol area, the Middle and, in part, the Southern Ural ${ }^{29}$. The "steppe signs" in the metal collection and the obvious "Alakul signs" in the ceramic set of Shaitanskoe Ozero II $^{30}$ illustrate close information contacts with the cultures of the steppe zone. It was from the steppe region that tin in the form of ingots or metal scrap and objects was delivered to the Ural. It is quite possible that the same corridors were used to bring to the Middle Trans Urals domesticated cattle, which could serve as an adequate equivalent in the intercultural dialogue.

A large sanctuary discovered on the shores of Shaitanskoe Lake near Yekaterinburg demonstrated the existence of a universal for the Eurasian territories practice of designating a large number of metal objects and other types of weapons, primarily stone arrowheads, for the sacred sphere $(80 \%$ of the total number of the known metal objects of the early Bronze Age in the Middle Trans-Urals). In addition, the archaeologists also found a large amount of metal production waste, which illustrated the specifics of the mythological and ritual practices followed by the participants of the ceremonies observed at the site $^{31}$. Significant changes in the way of life of the Ural population came as a direct result of the "metallurgical revolution" accompanied by a series of discoveries in the fields of food production, development of transport, communications, and the division of labor.

The consequences of the processes of transition to the age of metal in the mountain-forest zone of the Trans-Urals and Western Siberia were different. Owing to the extreme conditions of the second half of the Boreal, the population of the mountain-forest Trans-Ural experienced a severe crisis. Metalworking and metallurgy based on the division of labor and close integrations offered a new information resource and supported unique adaptations since the development of conversion technologies by the subsistence harvesting populations was an extremely rare phenomenon within the territory of Eurasia. It was then that the cultural potential necessary for one of the most striking evolutionary leaps in the region, a kind of a second metallurgical revolution of the $1^{\text {st }}$ millennium $\mathrm{BC}$, was formed.

In the taiga zone of Western Siberia, the vivid complexes rich in metal-bearing signs were replaced by feeble, unimpressive formations, which the archaeologists are still unable to identify. It is quite possible that these aberrations were caused by the fact that the local cultures in the absence of migrational traffic from other cultures "regained" their former appearance.

${ }^{28}$ Chernykh E.N., Orlovskaya L. B., Korochkova O. N. Issues in the calendar chronology of the SeimaTurbino Transcultural Phenomenon // Archaeology, Ethnology and Anthropology of Eurasia. 2017. Vol. 45, no. 2. P. 50-52.

${ }^{29}$ Korochkova O.N., Stefanov V.I., Spiridonov I.A. Srednee Zaural'e v kontekste Zapadnoaziatskoi Metallurgicheskoi Provintsii. P. 61-107.

30 Korochkova O.N., Spiridonov I.A. Stepnye znaki v metalle sviatilishcha Shaitanskoe Ozero II // Ural'skii istoricheskii vestnik. 2016. No. 4. P.69-71.

${ }^{31}$ Korochkova O. N., Stefanov V. I., Spiridonov I. A. Sviatilishche pervykh metallurgov Srednego Urala. Ekaterinburg, 2020. P. 28-50. 


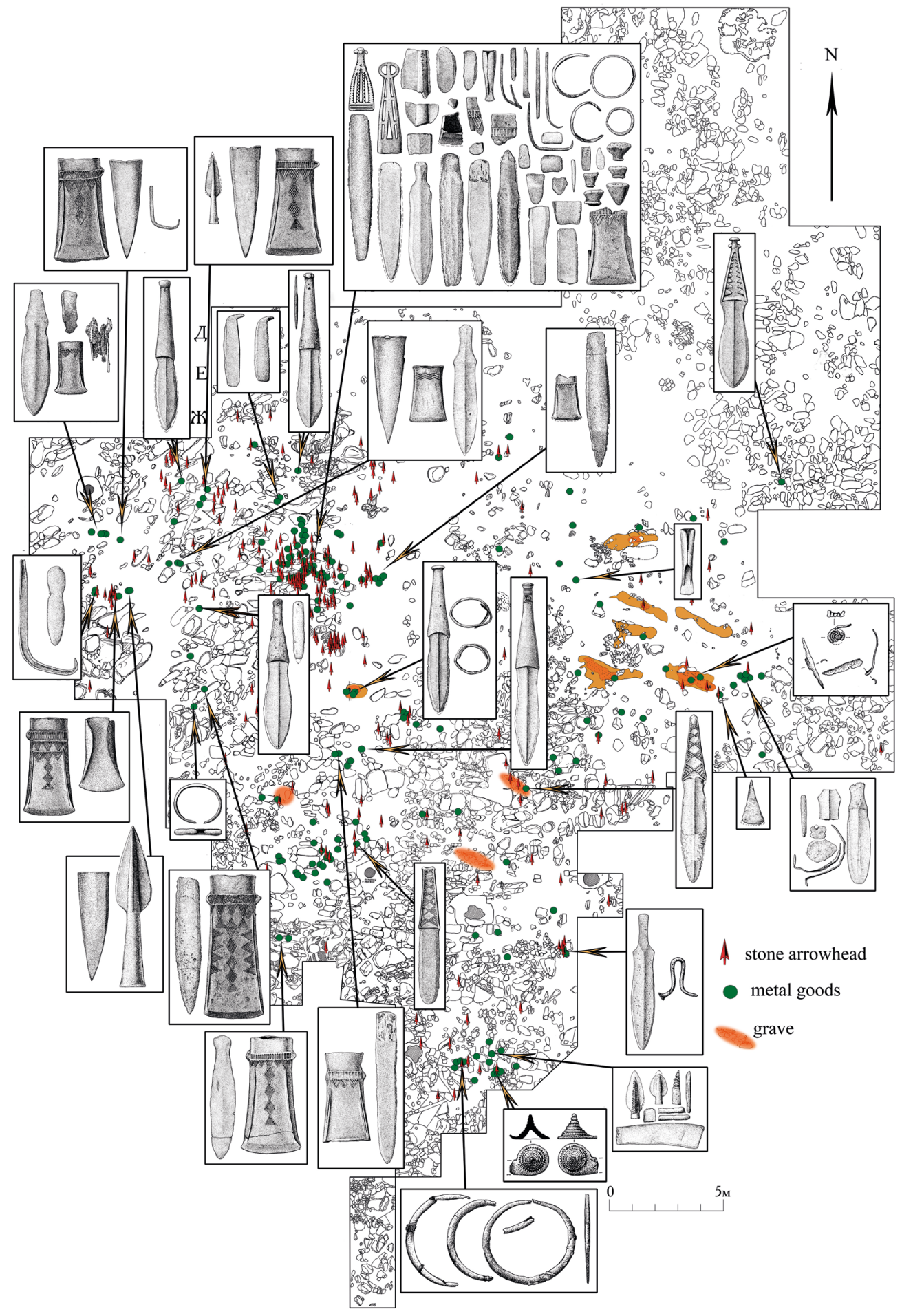

Fig. 5. Sanctuary of Bronze Age Shaitanskoyoe Ozero II. Sets of metal objects on the excavation plan (from [Korochkova O. N., Stefanov V. I., Spiridonov I. A., 2020]) 


\section{Early Iron Age}

By the end of the $2^{\text {nd }}$ millennium $\mathrm{BC}$ the differences in the land use patterns of the aborigines of the Ural and Western Siberia became particularly prominent. Life in the territory rich in copper deposits and the demand generated by the intensification of military conflicts in the nomadic world of the steppe zone caused reactivation of the store of knowledge preserved by the the metal-bearing cultures of the Middle Trans-Urals. A huge Itkul Mining and Metallurgical Center (MMC) based on collaboration between the nomadic pastoral communities of the steppe band and the Middle Trans-Urals metallurgists was formed in the area by the middle of the $1^{\text {st }}$ millennium $\mathrm{BC}^{32}$. It is symptomatic that the territories of the Koptyakov and the Itkul cultures connected with the main copper ore deposits of the region overlapped, however, the sites of the latter significantly outnumbered the former. A significantly increased density of population and the abundance of "Itkul metal" outside the territory of the MMC proper testify a successful life support model based on a reciprocity arrangement - cattle in exchange for metal, or, to be more exact, weapons. This model demonstrated a combination of various stimuli, the factors and conditions contributing to the formation of adequate responses to the challenges of the time. The archaeological data give evidence of an apparent division of labor traceable in the materials of the Itkul and the Iset cultures ${ }^{33}$. Of particular importance in the process was the pool of knowledge formed on the basis of the preceding Koptyakovo-Seima center, which combined the then rare skills of the miners, metallurgists and smelters. Because of the lack of tin, the local craftsmen developed their own original formulations ${ }^{34}$, improved the insert casting technology, and moved to the production of "standard models" for celts, arrowheads, and spearheads, the production of which was standardized, and followed the established technological procedures. The pronounced symbolism of the attributes related to metallurgical production (pestles for ore grinding with phallic symbols) was another confirmation of the existence of informational strain in this sphere of activity. The appearance of numerous copper cast items in the form of inverted images should be mentioned separately. Most of those items, sometimes in the form of quite large accumulations, was found in the dedicated locations on mountaintops. Thus, at that time, metal tools as such became quite common everyday items and one of the main exchange products; their production was based on the division of labor and the development of strict standards and regulations, while the symbolic attributes acquired an autonomous information significance. This kind of inversion (Fig. 6), when, if looked at from one angle the image was anthropomorphic, and from another - bird-like, indicated their extremely rich semantics, and the formation of a new mythology caused by the changes in the way of life ${ }^{35}$.

According to some experts, it was the Itkul impulse that signaled the beginning of the Iron Age in the north of Western Siberia, including in the forest-tundra zone. However, it

32 Bel'tikova G. V. Sreda formirovaniia i pamiatniki Zaural'skogo (itkul'skogo) ochaga metallurgii // Arkheologiia Urala i Zapadnoi Sibiri. Ekaterinburg, 2005. P. 162-170.

${ }^{33}$ Borzunov V.A. On the cultural attribution of the Itkul and Gamayun-Itkul antiquities of the TransUrals // Rossiiskaia arkheologiia. 2019. No. 3. P.131-146.

${ }^{34}$ Kuz'minykh S. V., Degtiareva A.D. Tsvetnaia metalloobrabotka itkul'skoi kul'tury (predvaritel'nye rezul'taty analiticheskikh issledovanii) // Vestnik arkheologii, antropologii i etnografii. 2015. No.4 (31). P. 65.

35 Viktorova V.D. Klady na vershinakh gor // Kul'tovye pamiatniki gorno-lesnogo Urala. Ekaterinburg, 2004. P. 170. 

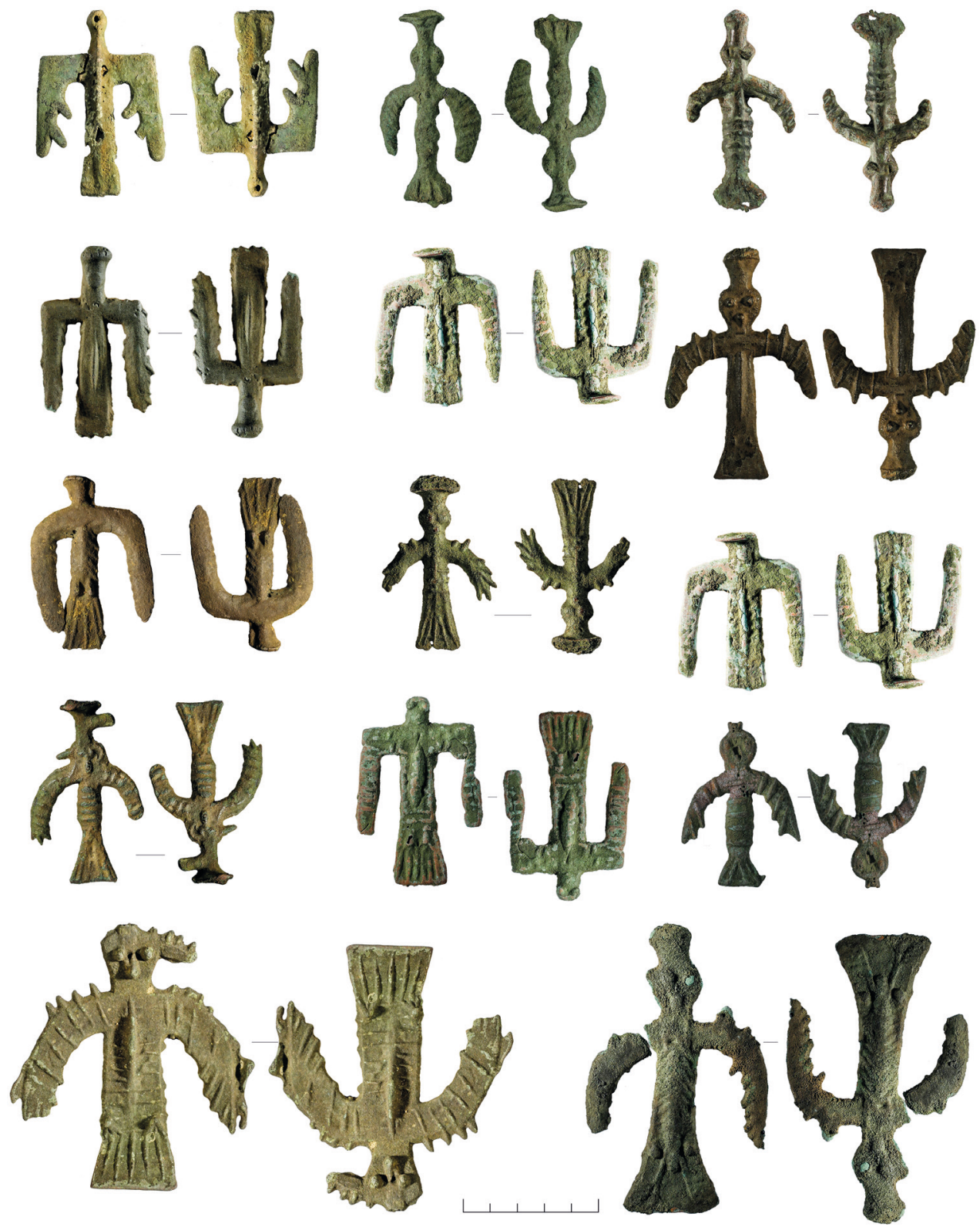

Fig. 6. Metal plates Itkul's culture of the Early Iron Age (remount after [Chemiakin Iu. P. Itkul'skie antropomorfy, poteriannye dlia nauk // Sed'mye Bersovskie chteniia. Ekaterinburg, 2016. Fig. 2])

would have faced more or less the same fate as the Seima-Turbino phenomenon, had it not been for a simultaneous occurrence of several factors in that area. By the turn of the eras, the local territories experienced a severe crisis caused by the changing climate. The established by that time life support strategies, apparently, could not sufficiently provide safe existence of the population. One of the responses to the new challenges was the develop- 
ment of deer herding ${ }^{36}$. The general presumption about the "import" of the deer herding from the Sayan-Altai region is not confirmed by the archaeological sources and significantly distorts the perspectives in the perception of potential of the north taiga aboriginal cultures which created an amazingly flexible system of mixed economy and demonstrated "high risk experiments and innovations"37. According to some researchers, the greater diversity of cultures in the North Eurasian area compared to the North American and Siberian (Eskimo) cultures was the result of the spread of reindeer herding ${ }^{38}$.

An extraordinary source of evidence of the scale of dramatic transformations of that period was the sanctuary and production center Ust Polui on the outskirts of the city of Salekhard. The cultural level of that site contained an unprecedented assemblage of artifacts and presented the unique archaeological situations providing solid arguments for the understanding of the causes and consequences of those changes. The researchers of the site, N.F. Fedorova and A. V. Gusev, viewed Ust Polui as the material embodiment of the world of three revolutions: the economic, the transportation and the symbolic ${ }^{39}$. I would also add the communication and food revolutions to their list. A contract with a reindeer may be compared in its consequences with the domestication of cattle, small stock, and horses. A reindeer compensated for practically all advantages of the steppe pastoralists' animals. It provided transport, food, skins for making homes and clothes, antlers and bones for making tools. Aborigines of the high latitudes crossed an immensely important threshold and moved, in fact, to food production and high mobility at a speed which was surpassed only by the end of the $20^{\text {th }}$ century. Food strategies were based on a comprehensive use of renewable resources (reindeer herding, fishing, gathering, hunting), which offered a rich diet and ensured the absence of fatal pathologies and infectious disease $\mathrm{e}^{40}$.

The evolution of reindeer herding may be compared in significance to the "domestication revolution". It brought about a series of social transformations reflected in the demographic growth, expansion of communications, marriage, kinship and in-law relationships, the drift of technologies, things, people, and inter-cultural dialogue. Archaeologically, this was reflected in a certain homogeneity of the cultural mosaic, in integration into the Eurasian world-system by means of trade connections, which stimulated the growth of the local economy focusing on rearing fur animals. The turbulent processes of social stratification and military tensions were reflected in the return of fortification practices, the formation of an elite subculture, which was manifest in the status and prestigious accessories and attributes, and the emergence of various kinds of weapons. Dramatic changes in the way of life were accompanied by the development of a metaphoric language of cultural codes implemented in the zoomorphic and anthropomorphic images ${ }^{41}$.

36 Fedorova N. V. Kaslanie dlinoi v dve tysiachi let: chelovek i olen' na severe Zapadnoi Sibiri // Ural'skii istoricheskii vestnik. 2006. No. 14. P.149-156; Gusev An. V., Plekhanov A. V., Fedorova N. V. Olenevodstvo na severe Zapadnoi Sibiri: rannii zheleznyi vek — srednevekov'e // Arkheologiia Arktiki. No. 3. Salekhard, 2016. P. 238-239.

37 Golovnev A. V. Antropologiya dvizheniya. P. 117.

38 Fitzhugh W. W. V poiskakh Graalia: tsirkumpoliarnaia teoriia i realii iamal'skoi arkheologii // Drevnosti Iamala. No. 1. Ekaterinburg; Salekhard, 2000. P. 26.

39 Fedorova N. V., Gusev An. V. Tri revoliutsii Ust'-Poluia. P. 196-206.

40 Fedorova N. V. Sever Zapadnoj Sibiri... P. 15-36.

41 Fedorova N. V. Antropomorfnye obrazy Ust'-Poluia: tekhnologiia, ikonografiia, kompozitsii stsen // Ural'skii istoricheskii vestnik. 2014. No. 2. P. 63-71; Fedorova N. V. Sever Zapadnoj Sibiri... P.37-56. 


\section{Conclusion}

The phenomenon of information explosions of prehistory in the territories in question reflected their unique place within the system of the subsistence harvesting cultures. Archaeological data provide direct evidence of breakthrough developments and the formation of adequate responses to the cognitive challenges of the high latitudes of Eurasia, and explain the diversity of forms of social and ideological adaptations, which confirms the concepts suggesting that humanity had "an unlimited number of evolutionary alternatives", and the path to civilization was not the only choice possible ${ }^{42}$.

\section{References}

Bel'tikova G. V. Environment of formation and monuments of the Trans-Urals (Itkul) center of metallurgy. Arkheologiia Urala i Zapadnoi Sibiri. Ekaterinburg, Izdatel'stvo Ural'skogo universiteta Press, 2005, pp. 162-186. (In Russian)

Besprozvannyi E.M., Degtiareva A.D., Korochkova O.N., Kuz'minyh S. V., Stefanov V.I., Kosinskaia L.L. Satyga XVI: Seima-Turbino burial ground in the taiga zone of Western Siberia. Ekaterinburg, Ural'skii rabochii Publ., 2011, 192 p. (In Russian)

Borzunov V.A. Fortified Eneolithic settlements in the taiga zone of the Ob River valley. Rossiiskaia arkheologiia, 2016, no. 3, pp.34-44. (In Russian)

Borzunov V. A. On the cultural attribution of the Itkul and Gamayun-Itkul antiquities of the Trans-Urals. Rossiiskaia arkheologiia, 2019, no. 3, pp. 131-146. (In Russian)

Borzunov V.A. The neolithic fortified settlements of the Western Siberia and Trans-Urals. Rossiiskaia arkheologiia, 2013, no. 4, pp. 20-34. (In Russian)

Borzunov V. A. Variants of Reconstruction and Development Trends of Stone and Bronze Age Stationary Dwellings in the Taiga Zone of Western Siberia. Stratum Plus, 2018, no. 2, pp. 347-375. (In Russian)

Borzunov V. A., Stefanov V.I., Glushkov I. G. Bystry Kulyogan-38 - Bronze Age fortified dwelling in the Surgut Ob Area. Archaeology, Ethnology and Anthropology of Eurasia, 2011, vol. 39, no. 2, pp. 55-69.

Chairkina N. M. The Eneolithic Of The Middle Urals. Ekaterinburg, UrO RAN Press, 2005, 312 p. (In Russian)

Chemiakin Iu. P. Itkul's ornithomorphices lost to science. Sed'mye Bersovskie chteniia. Ekaterinburg, Kvadrat Publ., 2016, pp. 265-273. (In Russian)

Chernykh E. N. Nomad's culture in the megastructure of the Eurasian World. Vol. 1. Moscow, Iazyki slavianskoi kul'tury Publ., 2013, 368 p. (In Russian)

Chernykh E. N., Orlovskaya L. B., Korochkova O. N. Issues in the calendar chronology of the Seima-Turbino Transcultural Phenomenon. Archaeology, Ethnology and Anthropology of Eurasia, 2017, no. 2, pp. 4555.

Dubrovsky D. K., Grachev V.Yu. Ural pisanitsy in the world rock art. Ekaterinburg, Grachev and Partners Publ., 2010, 216 p. (In Russian)

Fedorova N. V. A two-thousand-year-old kaslanie: Man and Deer in the north of Western Siberia. Ural'skii istoricheskii vestnik, 2006, no. 14, pp. 149-156. (In Russian)

Fedorova N. V. Anthropomorphic images of Ust-Poluy: technology, iconography and scenes composition. Ural'skii istoricheskii vestnik, 2014, no. 2 (43), pp. 63-71. (In Russian)

Fedorova N. V. North of Western Siberia in the Iron Age: traditions and mobility. Salekhard, Zolotoi tirazh Publ., 2019, 150 p. (In Russian)

Fedorova N. V., Gusev An. V. Three revolutions of Ust-Poluy. Kunstkamera, 2019, no. 3 (3), pp. 196-206. (In Russian)

Fitzhugh W. W. In search of the Grail: circumpolar theory and realities of Yamal archeology. Drevnosti Iamala. Vol. 1. Ekaterinburg; Salekhard, [s. n.], 2000, pp.25-53. (In Russian)

${ }^{42}$ Korotaev A. V., Kradin N.N., Lynsha V.A. Al'ternativy sotsial'noi evoliutsii (vvodnye zamechaniia) // Al'ternativnye puti k tsivilizatsii. Moscow, 2000. P.47-54. 
Golovnev A.V. Anthropology of movement. Ekaterinburg, UrO RAN Press, Volot Publ., 2009, 496 p. (In Russian)

Gusev An. V., Plekhanov A. V., Fedorova N. V. Reindeer herding in the North of Western Siberia: Early Iron Age-Middle Ages. Arkheologiia Arktiki, no.3. Salekhard, 2016, pp. 228-239.

Ivas'ko L. V. Fortified settlement of the Stone Age Kayukovo 2. Materialy i issledovaniia po istorii SeveroZapadnoi Sibiri. Ekaterinburg, UrGU Press, 2002, pp.7-25. (In Russian)

Kosintsev P. A., Bachura O.P. The mammals fauna of the North of Western Siberia in the Late Pleistocene and the Holocene. I Mezhdunarodnaia konferentsiia "Arkheologiia Arktiki". Salekhard, Delovaia pressa Publ., 2017, p. 13. (In Russian)

Korochkova O. N. Middle Trans-Urals and Taiga Ob' in the System of Relations of the West Asian Metallurgical province. Vestnik of Saint Petersburg University. History, 2019, vol.64, no. 2, pp. 718-739. (In Russian)

Korochkova O.N., Mosunova A.V. The Eneolithic complex of settlement Duvanskoe XVII. Vestnik arkheologii, antropologii i etnografii, 2018, no. 1 (40), pp. 5-15. (In Russian)

Korochkova O.N., Spiridonov I. A. Signs of the steppe in metal of Shaitan Lake II Sacred Place. Ural'skii istoricheskii vestnik, 2016, no. 4, pp. 68-76. (In Russian)

Korochkova O.N., Stefanov V.I., Spiridonov I. A. Sacred Place of the first metallurgists in the Middle Ural. Ekaterinburg, Izdatel'stvo Ural'skogo universiteta Press, 2020, 214 p. (In Russian)

Korochkova O.N., Stefanov V.I., Spiridonov I. A. The Central Trans-Urals in the Context of the Western Asian Metallurgical Province: the Koptyaki Culture Phenomenon. Stratum plus, 2019, no. 2, pp.61107. (In Russian)

Korotaev A. V., Kradin N. N., Lynsha V. A. Alternatives to social evolution (introductory remarks). Al'ternativnye puti $k$ tsivilizatsii. Moscow, Logos Publ., 2000, pp. 24-83. (In Russian)

Kuz'minykh S. V., Degtiareva A. D. Non-ferrous Metalworking of the Itkul culture (preliminary results of analytical studies). Vestnik arkheologii, antropologii i etnografii, 2015, no. 4 (31), pp. 57-66. (In Russian)

Matveev A. V., Matveeva N. P., Serikov Iu. B., Skochina S. N. Cult monuments of the Eneolithic Era. Tiumen, TiumGU Press, 2015, 156 p. (In Russian)

Morozov V.M., Stefanov V.I. Amnia I - the most ancient settlement of Northern Eurasia? Voprosy arkheologii Urala, 1993, vol. 21, pp. 143-163. (In Russian)

Mosin V.S., Shirokov V.N. New Paleolithic finds from the Southern Ural. Rossiiskaia arkheologiia, 2015, no. 1, pp. 153-156. (In Russian)

Lotman Yu. M. Culture and information. Semiosfera. St. Petersburg, Iskusstvo-SPb Publ., 2004, pp. 393-395. (In Russian)

Pavlov P. Yu. On the initial colonization of the North of Ural. Ural'skii istoricheskii vestnik, 2015, no.2, pp. 50-60. (In Russian)

Savchenko S. N., Zhilin M. G., Terberger T., Khoissner K. U. Idol in the context of the Early Mesolithic in the Trans-Ural. Ural'skii istoricheskii vestnik, 2018, no. 1, pp. 8-19. (In Russian)

Savinov D.G. Two ways of spreading bronze products of the Seyma type Eastwards. Arii stepei Evrazii: epokha bronzy i rannego zheleza v stepiakh Evrazii i na sopredel'nykh territoriiakh. Barnaul, Izdatel'stvo Altaiskogo universiteta Press, 2014, pp.91-99. (In Russian)

Serikov Yu. B. Ancient sanctuaries of the Tagil region. Nizhnii Tagil, NTGSPI Publ., 2017, 464 p. (In Russian)

Serikov Yu. B. Paleolithic and Mesolithic of the Middle Trans-Urals. Nizhnii Tagil, [s.n.], 2000, 430 p. (In Russian)

Sher Ia. A., Vishniatskii L. B., Blednova N.S. The origin of symbolic behavior. Moscow, Nauchnyi mir Publ., 2004, 280 p. (In Russian)

Shirokov V. N. Cave paleolythic art of the Ural and Western Europe. Ural'skii istoricheskii vestnik, 2013, no. 4, pp. 88-99. (In Russian)

Shirokov V.N., Chairkin S. E. Rock paintings of the Northern and Middle Urals. Ekaterinburg, [s.n.], 2011, 182 p. (In Russian)

Shirokov V.N., Petrin V.T. The Art of the Ice Ages. Ignatievskaya and Serpievskaya 2 caves in the Southern Urals. Ekaterinburg, [s.n.], 2013, 190 p. (In Russian)

Shorin A.F. Koksharovsky Kholm. The sanctuary on the hill. Kul'tovye pamiatniki gorno-lesnogo Urala. Ekaterinburg, UrO RAN Press, 2004, pp. 87-93. (In Russian) 
Shorin A.F. Koksharovsky Kholm and Chertova Gora, two neolithic sanctuaries in the Urals and in Western Siberia: Similarities and Differences. Archaeology, Ethnology and Anthropology of Eurasia, 2017, vol. 45, no. 2, pp. 16-25.

Stefanov V. I. Mogil'nik Tovkurtlor 3: Seiminsko-Turbinskii sled v Nizhnem Priob’e. Rossiiskaia arkheologiia, 2006, no. 1, pp. 44-58. (In Russian)

Stefanov V. I., Borzunov V. A. Neolithic settlement of Amnia I (based on materials from excavations in 1993 and 2000). Barsova Gora: Drevnosti taezhnogo Priob'ia. Ekaterinburg, Surgut, Ural'skoe izdatel'stvo Publ. 2008, pp. 93-11. (In Russian)

Viktorova V.D. Klady na vershinakh gor. Kul'tovye pamiatniki gorno-lesnogo Urala. Ekaterinburg, UrO RAN Press, 2004, pp. 158-173. (In Russian)

Vishnyatsky L. B. Information explosion and image-making. Archaeology, Ethnology and Anthropology of Eurasia, 2005, no. 1, pp.51-54.

Vishniatskii L. B. History of one accident. Friazino, Vek 2 Publ., 2005, 240 p. (In Russian)

Vishniatskii L. B. "The Upper Paleolithic Revolution": its geography, chronology, and causes. Stratum Plus, 2000, no. 1, pp. 245-271. (In Russian)

Zakh V. A., Skochina S. N., Parkhimovich S. G. Chepkul 21 underground burial ground in the north of the Andreevsky Lake System. Vestnik arkheologii, antropologii i etnografii, 2005, no. 6, pp. 24-42.

Zakh V. A., Zotova S. V., Panfilov A. N. Ancient burial grounds on Andreevsky lake near Tyumen. Drevnie pogrebeniia Ob'-Irtysh'ia. Omsk, OmGU Press, 1991, pp. 13-42.

Zolnikov I.D., Anoikin A.A., Makarov S.S., Postnov A. V., Rezvyi A.S., Glushkova N.V., Bychkov D. A., Tupakhin D.S., Vybornov A.V. About possible ways of human migrations into the territory of the Lower Ob in the Stone Age. Stratum Plus, 2020, no. 1, pp. 117-136. (In Russian)

Статья поступила в редакцию 9 апреля 2020 г.

Рекомендована в печать 12 марта 2021 г.

Received: April 09, 2020

Accepted: March 12, 2021 